\title{
RED-EYED VIREO MIMICS AN OLIVE-SIDED FLYCATCHER
}

Ron Jensen

1027 King Crescent

Saskatoon, SK S7K 0N9

rjes@shaw.ca

We were at Kimball Lake campground in Meadow Lake Provincial Park from June 29 to July 5,2014 . This note is an observation of a Red-eyed Vireo (Vireo olivaceus) that sang each morning from a birch tree about halfway between our campsite and the beach.

On the morning of June 30 at about 07:00 h, a Red-eyed Vireo started to sing the typical species song. Water levels were high in the park with our site adjacent to flooded woodland. Therefore, also hearing an Olive-sided Flycatcher (Contopus cooperi) calling was not unreasonable. I made a mental note to look for the Olive-sided Flycatcher.

Two days later, I set off to see the Red-eyed Vireo and the Olive-sided Flycatcher. I soon found the Red-eyed Vireo singing at the top of a white birch. The Olive-sided Flycatcher was not to been seen, but it also called from the same white birch. The vireo continued singing and the flycatcher continued to call. Where exactly was that flycatcher hiding? I trained my binoculars on the singing vireo. I could clearly see the vireo singing as it moved and fed. To my amazement, when the flycatcher called, the sound came not from an Olive-sided Flycatcher, but the Red-eyed Vireo!

A vireo accurately mimicking an Olive-sided Flycatcher. Now that the source of the Olive-sided Flycatcher call was resolved, I wondered if Redeyed Vireos were known mimics of other species. Where had this vireo learned to sing? Had this behaviour been reported before?

Bent (1965) reported "Several

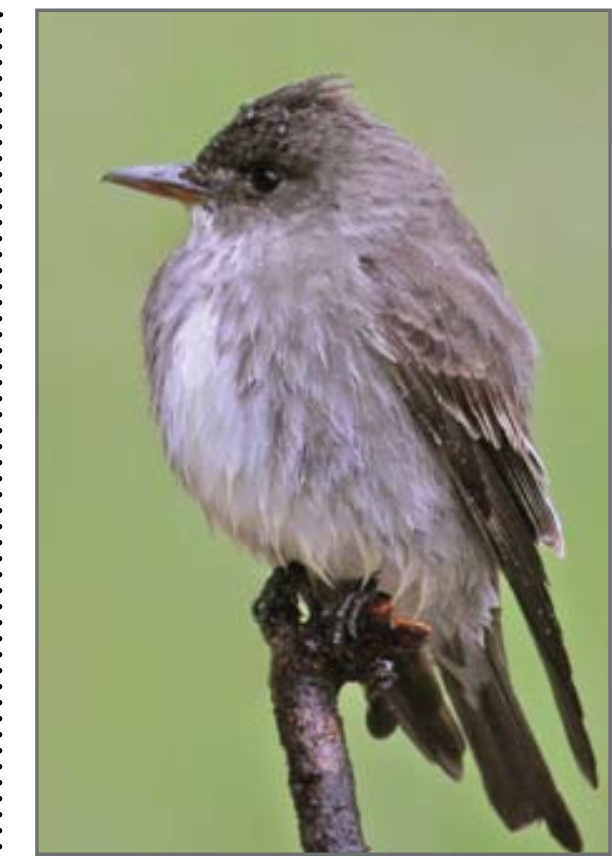

Olive-sided Flycatcher. Photo credit: Nick Saunders

observers have noticed that the bird [Red-eyed Vireo] occasionally introduces a phrase resembling a note of the crested flycatcher" and Francis H. Allen (MS.) says "I have heard it [Red-eyed Vireo] imitate the olive-sided flycatcher and the bluebird." "Bent states the quote came from an article published by Allen in Natural History. However, thanks to Stuart Houston, I can state with confidence that Allen may have said those words but they were not published in the Journal Natural History as referenced by Bent.

Additional literature searching found the following attributed to Mr. F.H. Allen, who was quoted saying "... has heard a Red-eyed Vireo introduce the call of the Bluebird in his song ..."2

A Red-eyed Vireo recorded at Ampersand Pond in the Adirondack Mountains by Peter Paul Kellogg and John Miller included a phrase from a Great Crested Flycatcher. "The audio file by Peter Paul Kellogg ...

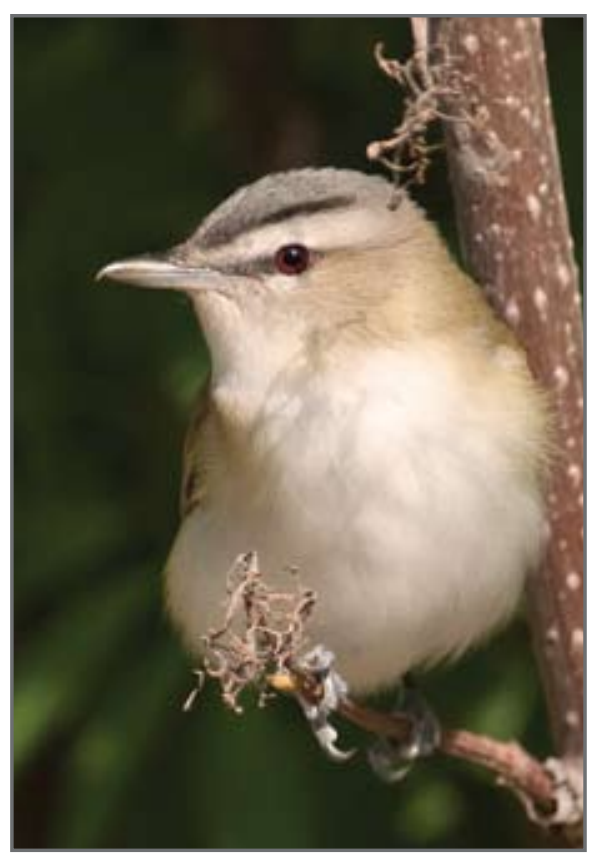

Red-eyed Vireo. Photo credit: May Haga

is ML $11825 \mathrm{http}: / /$ macaulaylibrary. org/audio/11825. ${ }^{3}$ The call of Great Crested Flycatcher is readily audible." 4

Ross James has the following comments:

"Near Dwight (Muskoka District), Ontario, on 12 July 1970, I recorded the song of a red-eyed vireo ... that periodically included a phrase, distinctly set off from the rest of its song, that closely resembled the song of an olive-sided flycatcher ... I heard this particular vireo singing through the summer, always with the flycatcher phrase in the song. Olivesided flycatchers lived in the general area, but none were heard within half a kilometer of this vireo.

"Comparing the vireo and flycatcher songs (Fig. 1) below, the vireo version omitted the first weak syllable of flycatcher song, the remaining two syllables are nearly

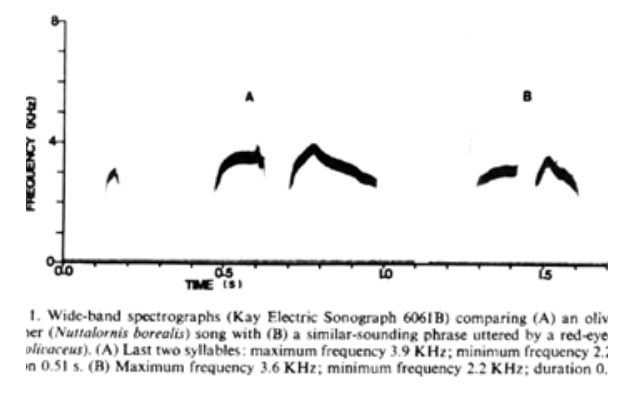


identical in form and frequency in both species, but the vireo sang these two syllables in a much shorter time than the flycatcher. Although red-eyed vireo song can be highly variable, particularly when the singer is stimulated by playback of the species-specific song (Lemon 1971), none of the published sonograms of this species resemble the 'flycatcher' phrase sung by this bird (Lemon 1971; Borror 1972), nor have I ever heard such a song from a red-eyed vireo in 10 years of studying vireos."

Figure 1 is provided with permission of the author, Ross James.

In reference to hybridization of similar species resulting in unusual or aberrant songs as suggested by Borror $1961^{6}$, Ross James questions whether hybridization among vireo species could account for the aberrant songs. He concludes with this statement:

"The presence of these unusual songs in red-eyed and warbling vireos strongly suggests that song learning also plays a part in song development in these species." ${ }^{5}$ James also states that "Similarly, a red-eyed vireo singing songs like those of a Towhee (Pipllo sp.) (Borror 1961) could not be the result of hybridization between these two species." ${ }^{5}$

Donald Kroodsma says "I've heard these vireos sing a mimicked call of a blue jay, for example, and other borrowed sounds ... I hear him [red-eyed vireo in his back yard] running through the familiar songs in his repertoire. Slower now, every few seconds ... there's the goldfinch imitation again, the 'question,' the whistle with rising inflection that the goldfinch uses to punctuate his song." 7

Paul Driver, on blogspot ${ }^{7}$, posted two sonograms and comments that "It is well-known that red-eyed vireos incorporate notes of other species into their songs. This bird included a Carolina Wren-like phrase and an

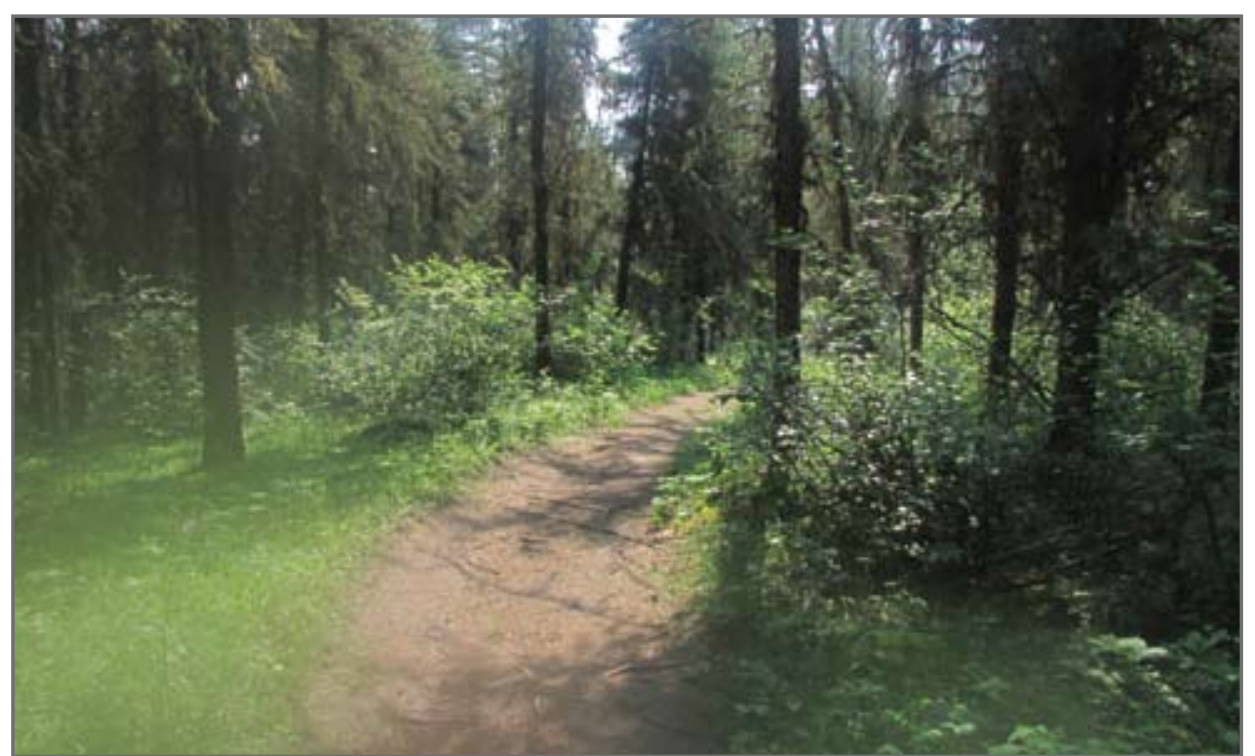

Figure 2. Mixed wood forest from Kimball Lake near Red-eyed Vireo site. Photo credit: Ron Jensen

Eastern Wood-Pewee-like call in its repertoire." 8

\section{A cautionary note written in} 1923 by Charles W. Townsend: "I am convinced that mimicry among our American birds is more common than is generally supposed. It follows, therefore, as a minor corollary that, while sight records are worthless unless the observer is known to be accurate, records by hearing alone, even if the recorder is an expert, may be worthless, owing to this prevalence of mimicry. Above all, one should be aware of the mimicry of that specialist, the European Starling." ${ }^{2}$

To summarize, Red-eyed Vireos have been reported making the calls of eight different species: Olive-sided Flycatcher, Great Crested Flycatcher, bluebird [presumably eastern], towhee of unknown species, American Goldfinch, Carolina Wren, Eastern Wood-Pewee and Blue Jay.

My casual observation of a Redeyed Vireo that included the call of an Olive-sided Flycatcher in his song repertoire turned into an interesting detective hunt.

I thank those who responded to e-mails searching for information on mimicry by Red-eyed Vireos: Stuart Houston, Philip Taylor, Greg Budney, Land Elliot, Andrew Horn, David
Kroodsma, John Neville and Russ Wigh. A further note of appreciation to the Blue Jay editor and an anonymous reviewer for their useful comments and beneficial edits.

1. In Bent, Life Histories of North American Wagtails, Shrikes, Vireos and Their Allies, Dover Edition, 1965. pp 343

2. Townsend, Charles W, 1924. Mimicry of Voice in Birds. Read at the meeting of the American Ornithologists' Union in Cambridge, October 9, 1923. Published in The Auk 41(4) pp 541-552 Oct 1924.

3. Audio recording, ML 11825, red-eyed vireo (Vireo olivaceus), Kellogg, Peter Paul and John Miller, United States, New York, Adirondack Mountains, Ampersand Pond, May 31, 1959, Macaulay Library, www.maclaylibrary.org, Cornell Lab of Ornithology.

4. Greg Budney personal e-mail correspondence.

5. James, Ross D. 1976. Unusual songs with comments on song learning among vireos. Can. J. Zool. 54(7) 1223-1226.

6. Borror, D.J. 1961. Intraspecific variation in passerine bird song. Wilson Bull. 73, 57-78.

7. Driver, Paul. 2010 July. 33 seconds. http://pjdeye.blogspot.ca/2010/08/redeyed-vireo-mimicry.html

8. Kroodsma, Donald E. 2005. The singing life of birds. The art and science of listening to birdsong. Houghton Mifflin Co. Boston, New York. 